\title{
INTEGRATED MARKETING COMMUNICATIONS PARADIGM IN DIGITAL ENVIRONMENT: THE FIVE PILLARS OF INTEGRATION
}

This paper is focused on the paradigm of integrated marketing communications (IMC) in digital environment. The integration is analysed through five aspects. First, integration in terms of media; it means that IMC are performed through the mix of traditional media (print - newspapers, magazines; radio; television; direct-response media - telephone, direct mail, catalogue marketing; billboards; other "specific media": product - especially brand, packaging; price; place; people; process; physical evidence; traditional/offline consumers - WOM communications) and digital media ( the Internet; mobile phones and other mobile devices; digital newspapers and magazines through the Internet and mobile devices; digital radio; digital TV; digital consumers - digital WOM communications). Second, integration in terms of communication methods, it means that IMC are a mix of traditional promotion (advertising, personal selling, public relations \& publicity, direct marketing, sales promotion), digital communications/interactions (Internet communications, mobile communications, communications via digital radio and TV) and WOM communications/interactions (offline and online). Third, integration in terms of time of communications and possibilities for interaction, it means that IMC are a mix of traditionalstatic communications ("monologue" towards the target audience) and dynamic communications ("dialogue") in real time. Fourth, integration in terms of actors, it means that IMC are a mix of communications initiated both by consumers (WOM communications - offline and online/e/digital) and organizations. Fifth, integration in terms of content creation, it means that IMC are a mix of communications based on consumer generated content and marketing content (created by organisations).

Key words: integrated marketing communications, paradigm, traditional communication, digital communication, WOM communications

Prof. Beba Rakić, PhD, Faculty of Business Studies, Megatrend University, Belgrade, e-mail: brakic@megatrend.edu.rs

* Prof. Mira Rakić, PhD, Faculty of Business Studies, Megatrend University, Belgrade 


\section{Introduction}

Redirection from the organization monologue towards consumers to the dialogue and interactions with consumers in real time is enabled by the development of Web-a 2.0. As Brennan ${ }^{1}$ states, Web 2.0 is used to describe the similar concept of the Internet's evolution from a static environment focused on the oneway provision or receipt of information (Web 1.0), to an interactive community where users can communicate, share, post, blog and create content in real time. "The information technology and information sector within the modern global economy have become a hard core of successful functioning and development of strategies of all entities in economic and social life". ${ }^{2}$ Cory emphasizes the changes in communications towards social media marketing communications. ${ }^{3}$ The author advises - online reputation is critical. Therefore, one should not talk at people; instead, one should talk with them and to do so in a manner that makes it clear organisation would like them to join the conversation. Jackson ${ }^{4}$ explains that new media technologies - the Internet, mobile broadband, e-commerce, internet-enabled entertainment, social networking, and others - are fundamentally changing the way people interact with each other and the world. Manolica ${ }^{5}$ states that social media represent a paradigm shift in the way that we as people communicate and interact with one another.

Hanna, Rohm and Crittenden ${ }^{6}$ bring up an important difference between traditional and social media. Traditional media is all about reach. But, while reach can be achieved in large numbers, it often does not translate into a true marketing exchange. Consumers become innocent, and often unwilling, bystanders in the actions of marketers. Digital technology allows the transformation of bystanders into active participants. Besides, consumers now also expect to be active participants in the media process. This requires new approaches to media strategy, involving media that do not simply replace traditional media, but rather expand media choices so as to capture reach, intimacy, and engagement.

1 Brennan Valerie (2010): "Navigating Social Media in the Business World", The Licensing Journal, vol. 30, issue 1, 8-12.

$2 \quad$ Kotlica Slobodan (2013): “The potential impact of information technology on the restructuring of the Serbian economy", Megatrend Review, Vol. 10, no 1, 205.

3 Cory Jesse (2010): “Social Media Comes of Age”, QR - Qualified Remodeler, vol 36, issue 5, 79-87.

$4 \quad$ Jackson Stuart (2010): "New media: debunking the myths", Journal of Business Strategy, vol. 31 , issue $1,56-58$.

5 Manolica Adriana (2011): Mixing Social Into Social Media: On-line Networking Is Transforming The Way Of Business All Over The Globe, CES Working Papers, III, (3), 405.

$6 \quad$ Hanna Richard, Rohm Andrew and Crittenden Victoria (2011): "We're all connected: The power of the social media Ecosystem", Business Horizons, vol. 54, issue 3, 265-273. 
Corcoran ${ }^{7}$ classifies all media into three groups:

- $\quad$ owned media (controlled by the marketer; e.g. company website, mobile site, blog, Twitter account);

- $\quad$ paid media (bought by the marketer; e.g., display ads, paid search, sponsorships);

- $\quad$ and earned media (not controlled or bought by the marketer; e.g., WOM).

The rest of the paper is organized as follows: Section 2 focuses on an integrated approach to traditional and new digital media. Section 3 presents an integrated approach to traditional and digital marketing communications. Section 4 examines an integrated approach to actors in the process of communications. Section 5 presents integrated marketing communications paradigm, which is based on five pillars. Section 6 briefly summarises the paper and its contributions.

\section{An integrated approach to traditional and new digital media}

Authors underline the changes in IMC as a result of social media impact, but they also say that social media present only a part of IMC strategy and of an integrated marketing strategy. Murray ${ }^{8}$ states that social media requires integration with traditional marketing.

"Social media's marketing potential is lost if it is not woven into the overall marketing strategy." The tools and strategies for communicating with customers have changed significantly with the emergence of the social media. ${ }^{9}$ Hanna, Rohm and Crittenden suggest the creation of ecosystem of related elements involving both digital and traditional media, strategic integration of social media into a firm's marketing communications strategy, and social media marketing as a mandatory element of their marketing strategy. ${ }^{10}$ They conclude that it is no longer enough to merely incorporate social media as standalone elements of a marketing plan. Companies need to consider both social and traditional media as part of an ecosystem whereby all elements work together toward a common objective. Marketing managers are seeking ways to incorporate social media into their

7 Corcoran Sean (2009): Defining owned, earned, and paid media, [Online], Available: http://blogs.forrester.com/interactive_marketing/2009/12/defining-earned-owned-andpaid-media.html [7 Aug 2013].

$8 \quad$ Murray David (2010): “Boosting Social Media Traffic: Who Goes There?”, Franchising World, vol. 42, issue 10, 17.

9 Hanna Richard, Rohm Andrew and Crittenden Victoria (2011), 270.

10 Hanna Richard, Rohm Andrew and Crittenden Victoria (2011): "We're all connected: The power of the social media Ecosystem”, Business Horizons, vol. 54, issue 3, 269. 
IMC strategies. ${ }^{11}$ Mangold and Faulds ${ }^{12}$ propose that social media be considered a hybrid component of the promotional mix and therefore be incorporated as an integral part of the organisation's IMC strategy. They compare and contrast the traditional communications paradigm that relied on the established promotional mix, elements which were developed and refined over the past 100 years, with the new communications paradigm which incorporates social media. First, in a traditional sense social media enable companies to talk to their customers, and this role of social media is consistent with the use of traditional IMC tools. Second, in a non-traditional sense social media enable customers to talk directly to one another - it is an extension of traditional word-of-mouth communication. Third, social media also enable customers to talk to companies, which is important for marketing research. "The content, timing, and frequency of the social mediabased conversations occurring between consumers are outside managers' direct control. This stands in contrast to the traditional integrated marketing communications paradigm whereby a high degree of control is present." So, according to the new communications paradigm, presented by Mangold and Faulds ${ }^{13}$, communications are performed integrally - by combining traditional promotion mix (advertising, personal selling, public relations and publicity, direct marketing and sales promotion) and social media (blogs - company sponsored and user sponsored, social networking sites, video sharing sites, etc.).

With the development of digital media, consumers change their behaviour, so that they redirect from traditional (classic) to digital media. However, consumers use different media, i.e. the mix of media, so that organisations also need to create messages for different media, i.e. a different acceptance of media by the consumers. Figure 1 shows an integrated approach to the media - both traditional and new digital.

$11 \quad$ Li Charlene and Bernoff Josh (2008): Groundswell: Winning in a world transformed by social technologies, Boston: Harvard Business Press.

12 Mangold Glynn and Faulds David (2009): "Social media: The new hybrid element of the promotion mix", Business Horizons, vol. 52, issue 4, 357.

13 Ibid, 357. 
Figure 1: Integrated approach to the media - both traditional and new digital

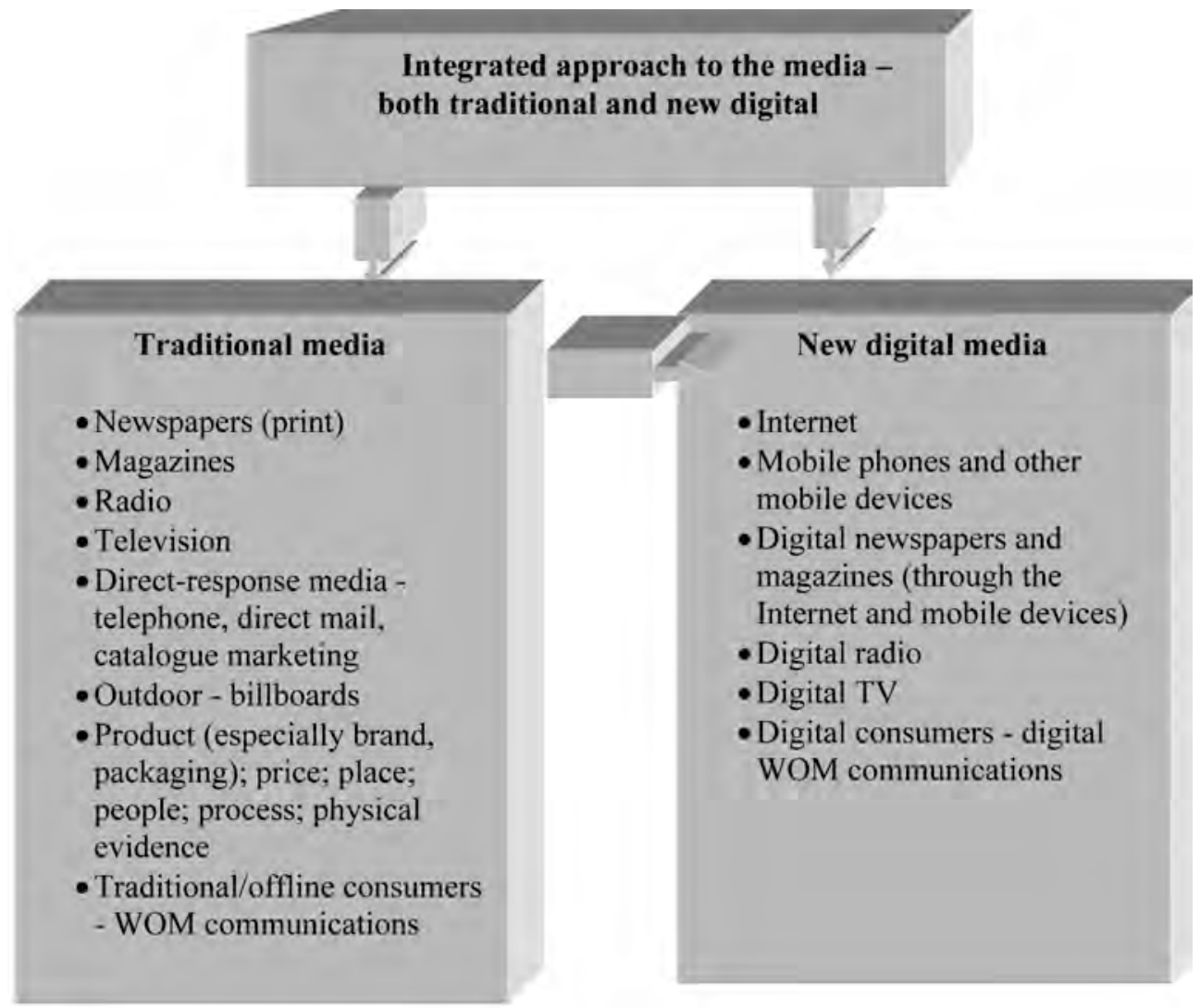

Consumers use traditional media such as newspapers (print), magazines, radio, television, direct media - telephone, mail, catalogues, external advertising etc. In addition to these typical traditional media, other instruments of marketing mix are equally important. These instruments are not directly focused on the promotion but they can be considered media as well and they represent product / organisation. Nowadays when consumers are constantly "bombarded" by advertising messages and when they do not pay attention to them, it is necessary to have media which would attract the attention of consumers. Such media can be effective packaging. To be specific, consumers can avoid watching TV video clips, they can choose not to listen to radio messages, look at all billboards and thus to avoid influences of typical media. However, when they find themselves in a store, an effective packaging can attract and keep the attention more than any other media. Price also "tells" a lot about the product, so it is an indirect medium. Distribution channels, retailers (knowledge, kindness, politeness, etc.), the process of service delivery, cordial atmosphere additionally represent product/organisation. As a result of the aforementioned influences of media, tradi- 
tional - offline consumers, through oral recommendation ("word of mouth" - in person), communicate their (dis)pleasure to others, and thus they become the most important i.e. the most influential "movable media".

The process of digitalisation influences the acceptance of new digital media like the Internet, mobile phones and other mobile devices (e.g. iPad), digital newspapers and magazines (through the Internet and mobile phones), digital radio, digital TV and digital consumers. Online consumers can quickly convey messages to multiple people - friends, acquaintances, but also to strangers.

The Internet, digital radio, digital TV, mobile phones and other mobile devices are used as:

- Media - channels of communication (as a part of multi-channel - integrated marketing communications) - for communications, interactions and relationships with customers and other actors in the micro-environment,

- sales channels,

- distribution channels - for digital products,

- the method of marketing research - consumers and all other actors and forces in the region.

\section{An integrated approach to traditional and digital marketing communications}

As Aprimo $^{14}$ states, every element in marketing mix of an organisation whether traditional or online - should share a consistent look and feel that aligns with company's goals.

Consumers behave differently; they use different media, so organisations use IMC. Digital communications are only a part of multi-channel, i.e. integrated communications. The real question is what mix of marketing communications should be used. Based on integrated marketing communications, organisation informs, persuades, reminds us "listens" to consumers about products/services and/or organisation.

\section{The methods of integrated marketing communications are:}

- Advertising - paid form of non-personal presentation of products or services of on organisation.

- Sales promotion - includes a variety of short-term incentives that encourage trial and / or purchase of products or services.

- Public relations and publicity are aimed to create and maintain a good image of an organization.

\footnotetext{
14 Aprimo (2011): Insights to Help Advance Digital Marketing, [Online], Available: http://
} research.itpro.co.uk/content12192 [11 Aug 2013]. 
- Traditional ways of direct communication like using mail, telephone, fax in order to establish direct communications and interactions.

- Personal selling is an interaction face-to-face between dealer and one or more potential buyers in order to organise presentations, answer questions, and obtain orders and product sales.

- Digital marketing communications - using the Internet, databases, mobile devices, digital radio and TV, and other (for the time being) new digital technologies for faster and more effective communications, interactions and the management of relationship with customers and other actors in the internal environment.

The above mentioned classic forms of communication, thanks to digital technology, get their appropriate digital forms. For example, the advertising in classic (traditional) printed newspapers and magazines on one hand, and advertising in digital newspapers and magazines (online and mobile) are different. Classic TV is replaced by Internet TV and digital TV.

Telephone communications are being diverted from landline phones to mobile phones. Mobile phones allow communications with mobile consumers - i.e. consumers on the move - anytime, anywhere - of course, if the consumers are interested in communications. Smart phones offer numerous possibilities for both consumers and organisations.

Organisations can send classic direct mail to a home address and / or to quickly send messages more quickly, electronically - via email.

In addition to traditional and digital methods of marketing communications, organisations present their products / services through non-communicative instruments of the marketing mix. All this together makes integrated marketing communications.

- Non-communicative instruments of marketing mix - product (above all brand and packaging), price, channels of distribution, people, process, physical evidence. All these instruments also "speak" a lot about the product and the organization. In other words, all instruments of marketing mix directly or indirectly represent products/services/organizations and can contribute to the value of products and to the experience of consumers.

- Word of Mouth Marketing (WOMM) aims to establish Word of Mouth (WOM) among users (word of mouth - communications "from mouth to mouth", i.e. word of mouse - communications "from mouse to mouse"). Communications among consumers are related to recommendations, comments, suggestions, reviews etc. All previously mentioned forms of IMC have great influence on WOM. This, and not the significance of WOM, is the reason why WOM is listed last. If we talk about their significance, WOM should be listed first. Numerous research results confirm that communications with family members, friends, acquaintances and 
customers have greater impact on consumers' behaviour than IMC of organisations.

Communications among users can be offline (e.g. from mouth to mouth) and online (e.g. through forums, blogs, social networks and other social media). The following terms are used: User Generated Media and User Generated Content.

Availability, prices and acceptance of new digital media by greater number of consumers - market, will in the end lead to the fact that they will also become classic.

\section{Integrated approach to actors in the process of communication}

Consumers via digital media take control over the communications about brands, so that they can initiate communications, they can be active participants and passive observers and not only the recipients of information. Nowadays, communications can be initiated by both organizations and consumers (Figure 2). Communications become two-way communications. Traditional organisation's monologue "to" consumers and stakeholders through traditional media is being supplemented by digital media that allow two-way communications and dialogue between consumers and organisation, but also among consumers themselves.

Figure 2: Actors in the process of IMC

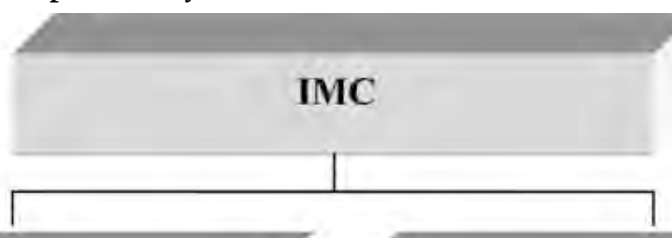

Organisation initiates communications

- Advertising

- Sales promotion

- Public relations

- Traditional ways of direct communication

- Personal selling

- Digital marketing communications

- Non-communicative instruments of marketing mix

- WOMM
Consumers - the key actors of communications (WOM)

- Offline - communications "from mouth to mouth"

- Online - communications "from mouse to mouse" (e.g. via social media)

- Communications "from mobile to mobile" phone 


\section{Integrated marketing communications paradigm: The five pillars of integration}

Integrated marketing communications paradigm is based on five aspects of integration (Figure 3).

Figure 3: The five pillars of the integrated marketing communications paradigm

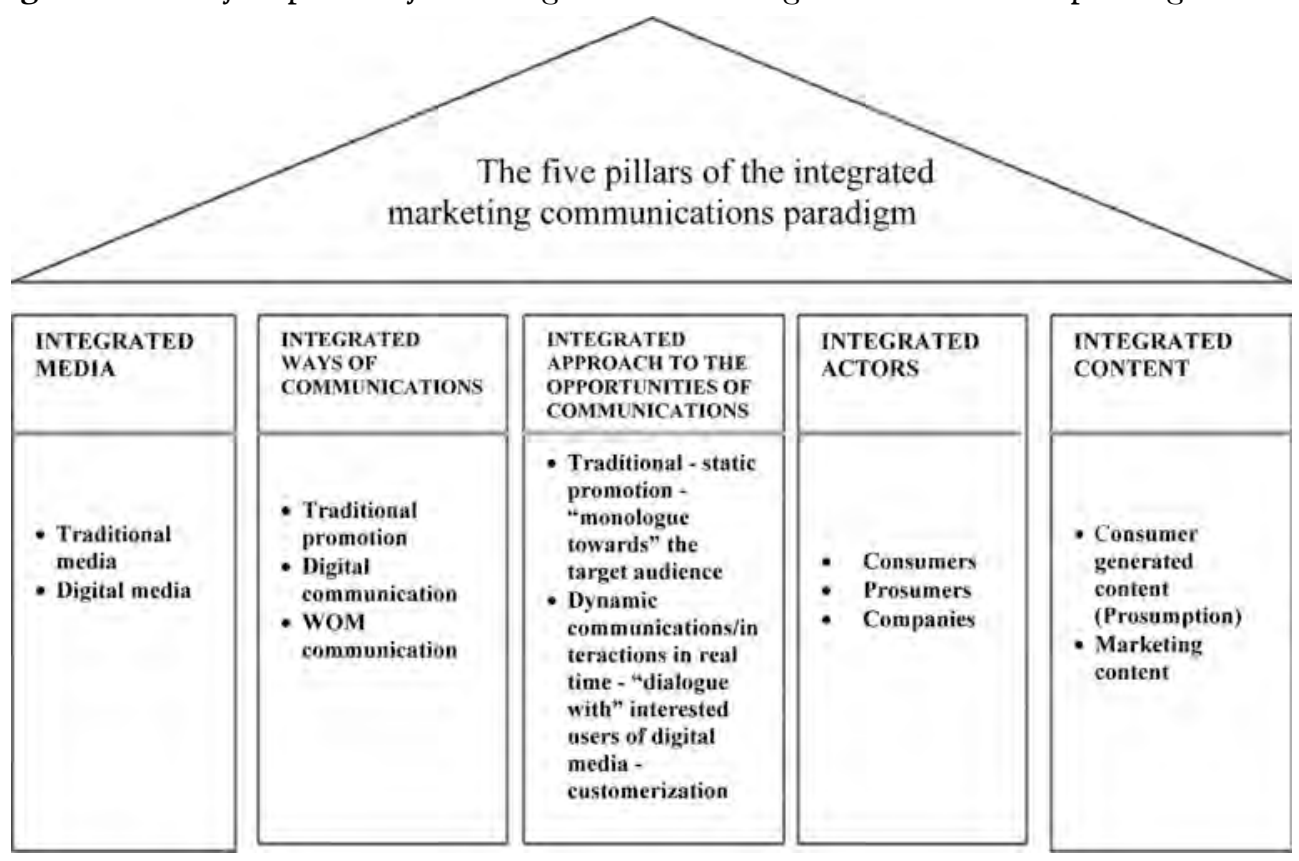

\subsection{Integrated media}

Before the advent of digital media, in order to promote themselves organisations used traditional media such as newspapers (print), magazines, radio, television, direct media - telephone, mail, catalogues, external advertising methods, other "specific media": product (especially the brand, packaging), price, distribution channels, people; process; physical evidence, traditional (offline) consumers - WOM. When digital media have been invented, consumers started increasingly to use them, so the companies had to start to communicate through digital media like the Internet, mobile phones and other mobile devices (e.g. iPad etc.), digital newspapers and magazines (via the Internet and mobile devices), digital radio, digital TV, digital consumers - digital WOM. Consumers use both traditional and digital media, so that integration in terms of media means that organisations also use all media in the process of IMC. 


\subsection{Integrated ways of communications}

Before the advent of digital media, organisations were conducting promotion based on traditional promotion mix - advertising, personal selling, public relations \& publicity, direct marketing, sales promotion. With the advent of digital media, organisations have begun to use also digital communication / interaction. Integration, in terms of methods of communications, means that organisations use both traditional promotion and digital communications, but they have to pay attention to WOM communications as well, and to stimulate them through word-of-Mouth Marketing - WOMM.

\subsection{Integrated approach to the opportunities of communications}

Before the advent of digital media, organisations were able to promote brands through traditional static forms (of promotion) based on "monologue towards" mass target audience. Digital media have provided opportunity for more dynamic communications - interactions in real time - real "dialogues with" all interested users (of digital media).

Wind and Rangaswamy ${ }^{15}$ propose that the next stage of evolution of mass customization is customerization - a buyer-centric company strategy that combines mass customization with customized marketing. Digital technologies and consumers will affect more and more the customerization of marketing and business activities $\mathrm{u}$ as a whole. In the old model-mass and segmented marketing, communications were reduced to advertising and PR. In the new model, marketing communications are integrated, interactive, and customised. For consumers education and entertainment, or as some authors ${ }^{16}$ call it "interactive edutainment", are also very important. "The customerization of the content, format, the educational component and the entertainment/ captivating power of the communication, its mode of delivery, and timing and place is becoming important to a segment of customers and will become an increasingly important part of the portfolio of communication activities of the firm". ${ }^{17}$

\subsection{Integrated actors}

Before the advent of digital media, the key initiators and actors in communications, especially in the promotion, were organisations. Digital media have provided opportunity for consumers to be active participants and initiators of

15 Wind Jerry and Rangaswamy Arvind (2001): "Customerization: The Next Revolution in Mass Customization”, Journal of Interactive Marketing, vol. 15, issue 1, 13-32.

16 Ibid.

17 Ibid, 24. 
communications. Integration in terms of actors means that both consumers and organisations take part in communications.

Since Toffler ${ }^{18}$ has first invented the term the "prosumer," numerous authors, talk about the importance of prosumers and prosumption, prosumer age, age of the digital prosumer and prosumer capitalism ${ }^{19} / 20 /^{21} f^{22} /^{23} /^{24} / 25$. Prosumer is the one who is both producer and consumer; and prosumption involves a combination of production and consumption. "Prosumption has always existed, but various social changes (e.g., the rise of the Internet and of social networking on it) have greatly expanded both the practice of prosumption and scholarly attention to it". ${ }^{26}$

\subsection{Integrated content}

Before the advent of digital media, content was usually created by organisations (excluding offline WOM communication). However, with the advent of digital media content can be created by consumers as well, who are the users of digital media. Integration in terms of content creation means that the organisation apart from content marketing has to pay attention to user-generated content. User-generated content represents "another way of saying prosumption".

\section{The process of communications based on integrated marketing communications paradigm}

Figure 4 shows the process of communications based on integrated marketing communications paradigm. Organisation together with agents (advertising agency, marketing research, public relations firm etc.) conducts promotion

18 Toffler Alvin (1980): The third wave, New York: William Morrow.

19 Collins Steve (2010): "Digital Fair: Prosumption and the Fair Use Defence", Journal of Consumer Culture, vol. 10, issue 1, 37-55.

20 Comor Edward (2011): “Contextualizing and Critiquing the Fantastic Prosumer: Power, Alienation and Hegemony", Critical Sociology, vol. 37, issue 3, 309-327.

${ }_{21}$ Cook Willam (1997): "World Wide Wake-Up Call”, Journal of Advertising Research, March-April, 5.

22 Davis Jenny (2012): "Prosuming Identity: The Production and Consumption of Transableism on Transabled.org", American Behavioral Scientist, vol. 56, issue 4, 596-617.

23 Rey P. (2012): “Alienation, Exploitation, and Social Media”, American Behavioral Scientist, vol. 56 , issue $4,399-420$.

24 Ritzer George and Jurgenson Nathan (2010): "Production, Consumption, Prosumption: The Nature of Capitalism in the Age of the Digital "Prosumer", Journal of Consumer Culture, vol. 10, issue 1, 13-36.

25 Ritzer George, Dean Paul and Jurgenson Nathan (2012): “The Coming of Age of the Prosumer", American Behavioral Scientist, vol. 56, issue 4, 379-398.

26 Ibid, 379.

Vol. 11, No 1, 2014: 187-204 
through promotion mix and digital marketing communications with consumers. Consumers can take part in each other's communications, both face-to-face (offline), and through social media. Consumers can take part in communications with representatives of the organisation. ${ }^{27}$

Figure 4: The process of communications based on integrated marketing communications paradigm

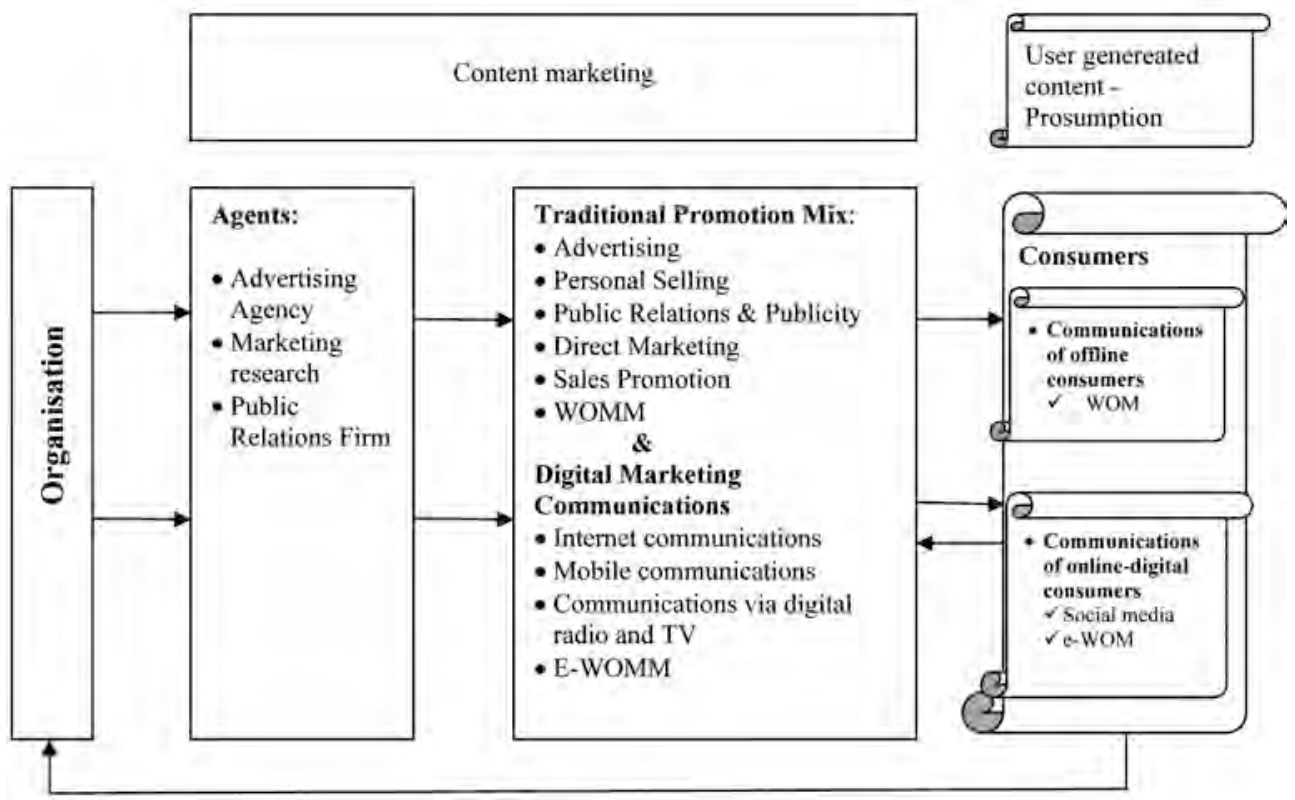

Source: Done and adapted from: Mangold and Faulds, 2009: 360.

\section{Summary}

Digital environment affects changes in IMC. In the age of prosumption and prosumers, organisations are faced with the challenge of the choice of IMC. Consumers behave differently, follow different media, in different context and time. Consumers have different approaches to marketing communications - some are just passive observers of organisations' promotions and interactions, while others are active participants in their mutual interactions via social media and in interactions with organisations in real time. Traditionally oriented consumers are more directed towards traditional communications. Digitally oriented consumers are equipped with smart devices and are ready for digital communications and interactions in real time. The consumers in the digital era, with the

$27 \quad$ Ibid, 386-387. 
digital mind-set, are not only up to date with the digital communications, but they are prosumers of marketing content.

On one hand, technologies, media and communications are changing, i.e. they are getting more and more digitised. On the other hand, companies must at least follow the changes, i.e. they have to digitise their business entirely. Organisations respond to that by using the mix of traditional and digital media, communications and business. Integrated marketing communications paradigm suggested in this paper starts from traditional marketing communications and it takes into account changes in the environment. Integrated marketing communications paradigm is based on the five pillars of integration - integrated: media, methods of communications, communications' opportunities, actors and content. First, integration in terms of media means that IMC are performed through the mix of traditional and digital media. Second, integration in terms of communication methods means that IMC are a mix of traditional promotion and interactions among the consumers, as well as among the consumers and organisations. Third, integration in terms of time of communications and possibilities for interactions means that IMC are a mix of traditional-static communications ("monologue" towards the target audience) and dynamic communications ("dialogue") in real time. Fourth, integration in terms of actors means that IMC are a mix of communications initiated both by consumers (WOM) and organisations. Prosumers are co-creators of the content in the process of IMC. Fifth, integration in terms of content creation means that IMC are a mix of communications based on consumer generated content and marketing content (created by organisations). Consumers take part in the process of prosumption.

Shift towards digitisation of communications and, widely observed of entire business, is a part of a general process of digitisation which is rapidly becoming a requirement for survival in a competitive environment. Prosumers and prosumption in marketing communications are only a part of the general trend towards and prosumption.

Digitisation of consumers, media and environment affects the customerization of communications, marketing and business as a whole. "Customerization is not a strategy that replaces traditional mass marketing, but rather it offers additional competitive options in developing an overall marketing strategy". ${ }^{28}$ Customerization of marketing communications is a part of the integrated customerization strategy. The conditions for application for customerization strategy of marketing communications are: digital orientation and processes; digital education and the willingness of employees to perform digital communications in real time; digitisation of the content and the ways of marketing communications.

Consumers can variously be engaged in the process of marketing communications of organisations (they can be completely passive and/or passive observers and/or active participants - co-creators/co-producers of content - prosum-

$28 \quad$ Wind Jerry and Rangaswamy Arvind (2001), 26.

Vol. 11, No 1, 2014: 187-204 
ers) they can follow different media, in different periods of time, context and so on. On the other hand, it is important for organisations to have an integrated approach to marketing communications. Integrated - combined traditionally digital access to communications is the organisations' response to changes in the digital environment. IMC are a mixture of traditional and digital communications; traditional, static promotion - mass advertising and dynamic - customised interactions; content created by organisations and prosumers; and it is transmitted through traditional and digital media. An integrated approach to marketing communications enables an integrated representation in all touch points with consumers and integrated experience for the consumer. IMC are only a part of the marketing and business strategy. Integrated (combined traditional-digital) approach to communications is only a part of the integrated (combined traditional-digital) approach to marketing strategy and business strategy as a whole.

In short, in the digital environment, consumers' behaviour is a mix of traditional and digital. Integrated marketing communications (and business in general) are a mixture of traditional and digital.

\section{Literature}

- Aprimo (2011): Insights to Help Advance Digital Marketing, [Online], Available: http://research.itpro.co.uk/content12192 [11 Aug 2013].

- Brennan Valerie (2010): "Navigating Social Media in the Business World", The Licensing Journal, vol. 30, issue 1, 8-12.

- Collins Steve (2010): "Digital Fair: Prosumption and the Fair Use Defence", Journal of Consumer Culture, vol. 10, issue 1, 37-55.

- Comor Edward (2011): "Contextualizing and Critiquing the Fantastic Prosumer: Power, Alienation and Hegemony", Critical Sociology, vol. 37, issue 3, 309-327.

- Cook Willam (1997): “World Wide Wake-Up Call”, Journal of Advertising Research, March-April, 5.

- Corcoran Sean (2009): Defining Owned, Earned, and Paid Media, [Online], Available: http://blogs.forrester.com/interactive_marketing/2009/12/ defining-earned-owned-and-paid-media.html [7 Aug 2013].

- Cory Jesse (2010): "Social Media Comes of Age", QR - Qualified Remodeler, vol 36, issue 5, 79-87.

- Davis Jenny (2012): "Prosuming Identity: The Production and Consumption of Transableism on Transabled.org", American Behavioral Scientist, vol. 56, issue 4, 596-617.

- Hanna Richard, Rohm Andrew and Crittenden Victoria (2011): "We're all connected: The power of the social media Ecosystem", Business Horizons, vol. 54, issue 3, 265-273. 
- Jackson Stuart (2010): “New Media: Debunking the Myths", Journal of Business Strategy, vol. 31, issue 1, 56-58.

- Kotlica Slobodan (2013): “The Potential Impact of Information Technology on the Restructuring of the Serbian Economy", Megatrend Review, vol. 10, issue 1, 197-208.

- $\quad$ Li Charlene and Bernoff Josh (2008): Groundswell: Winning in a world transformed by social technologies, Boston: Harvard Business Press.

- Mangold Glynn and Faulds David (2009): "Social Media: The New Hybrid Element of the Promotion Mix", Business Horizons, vol. 52, issue 4, 357-365.

- Manolica Adriana (2011): Mixing Social Into Social Media: On-line Networking Is Transforming The Way Of Business All Over The Globe, CES Working Papers, III, (3), 404-414.

- Murray David (2010): "Boosting Social Media Traffic: Who Goes There?", Franchising World, vol. 42, issue 10, 15-17.

- Rey P. (2012): "Alienation, Exploitation, and Social Media", American Behavioral Scientist, vol. 56, issue 4, 399-420.

- Ritzer George and Jurgenson Nathan (2010): "Production, Consumption, Prosumption: The Nature of Capitalism in the Age of the Digital "Prosumer", Journal of Consumer Culture, vol. 10, issue 1, 13-36.

- Ritzer George, Dean Paul and Jurgenson Nathan (2012): “The Coming of Age of the Prosumer", American Behavioral Scientist, vol. 56, issue 4, 379-398.

- Toffler Alvin (1980): The third wave, New York: William Morrow.

- Wind Jerry and Rangaswamy Arvind (2001): "Customerization: The Next Revolution in Mass Customization", Journal of Interactive Marketing, vol. 15, issue 1, 13-32.

Paper received: January $27^{\text {th }}, 2013$

Upon the request of reviewers, revised:

February $24^{\text {th }}, 2014$

Approved for publication: February $24^{\text {th }}, 2014$
Rad primljen: 27. januar 2014.

Prema zahtevu recenzenta, dorađen:

24. februar 2014. Odobren za štampu: 24. februar 2014. 


\section{Prof. dr Beba Rakić}

Fakultet za poslovne studije, Megatrend univerzitet, Beograd

Prof. dr Mira Rakić

Fakultet za poslovne studije, Megatrend univerzitet, Beograd

\section{PARADIGMA INTEGRISANIH MARKETINŠKIH KOMUNIKACIJA U DIGITALNOM OKRUŽENJU: PET STUBOVA INTEGRISANOSTI}

\section{S a ž e t a k}

U fokusu rada je paradigma integrisanih marketinških komunikacija (IMK) u digitalnom okruženju. Digitalni mediji i ponašanje potrošača utiču na promene integrisanih marketinških komunikacija. Neophodan je integrisani pristup tradicionalnim i digitalnim medijima i komunikacijama. Integrisanost se posmatra sa pet aspekata. Prvo, integrisanost s aspekta medija, znači da se IMK ostvaruju na osnovu miksa tradicionalnih i digitalnih medija. Drugo, integrisanost s aspekta načina komunikacija, znači da IMK predstavljaju miks tradicionalne promocije i interakcija, kako između samih potrošača, tako i između potrošača i organizacija. Treće, integrisanost s aspekta vremena komunikacija i mogućnosti za interakcije znači da su IMK miks tradicionalnih statičkih komunikacija („monologa“ prema ciljnom auditorijumu) i dinamičkih komunikacija („dijaloga“) u realnom vremenu. Četvrto, integrisanost s aspekta aktera, znači da IMK predstavljaju miks komunikacija koje iniciraju i potrošači (WOM) i organizacije. U digitalnom veku, digitalno usmereni potrošači, opremljeni smart uređajima, ne samo da prate digitalne komunikacije, već su i proizvođači i potrošači (prosumers) marketinškog sadržaja. Peto, integrisanost s aspekta kreiranja sadržaja, znači da IMK predstavljaju miks komunikacija na osnovu sadržaja koji kreiraju potrošači i marketinga sadržaja (koji kreiraju organizacije). Potrošači učestvuju u procesu i proizvodnje i potrošnje (prosumption).

Digitalizacija medija, komunikacija i okruženje utiču na kastomerizaciju (customerization), komunikaciju, marketing i poslovanje organizacije u celini. Uslovi za primenu strategije kastomerizacije marketinških komunikacija su: digitalna orijentacija i procesi; digitalno obrazovanje i spremnost zaposlenih na digitalne komunikacije u realnom vremenu; digitalizacija sadržaja i načina marketinških komunikacija.

Potrošači mogu različito da se angažuju u procesu marketinških komunikacija organizacija (da budu potpuno pasivni i/ili pasivni posmatrači i/ili aktivni učesnici, tj. kokreatori sadržaja), prate različite medije, u različitim periodima, kontekstu itd. Na drugoj strani, bitno je da organizacije imaju integrisani pristup marketinškim komunikacijama. Integrisani - kombinovani tradicionalno-digitalni pristup komunikacijama je odgovor organizacija na promene u digitalnom okruženju.

Ukratko, u digitalnom okruženju ponašanje potrošača je miks tradicionalnog i digitalnog. IMK su miks tradicionalnih i digitalnih komunikacija; tradicionalne, statičke promo- 
cije - masovnog oglašavanja i dinamičkih - prilagođenih interakcija; sadržaja koji kreiraju organizacije i korisnici, i prenosi se putem tradicionalnih i digitalnih medija. Integrisani pristup marketinškim komunikacijama omogućava integrisano predstavljanje u svim „tačkama dodira“ (touch-points) sa potrošačima i integrisano iskustvo za potrošača.

Ključne reči: integrisane marketinške komunikacije, paradigma, tradicionalne komunikacije, digitalne komunikacije, WOM komunikacije 